\title{
Stereolithography Models
}

\author{
Kansas City Division
}

R. E. Smith

KCP-613-5518

Published March 1995

Final Report

Approved for public release; distribution is unlimited.

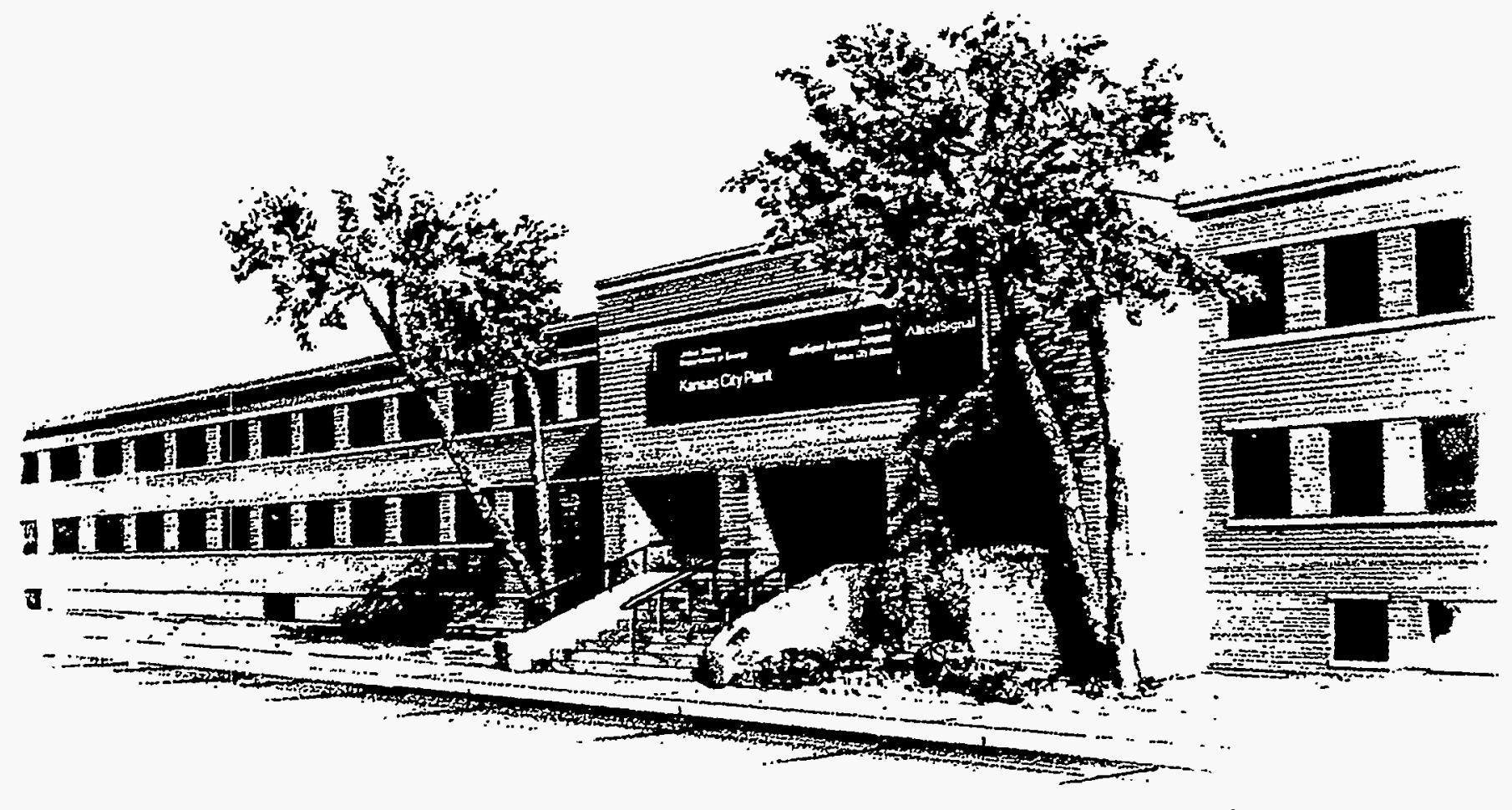

Prepared Under Contract Number DE-AC04-76-DP00613 for the United States Department of Energy

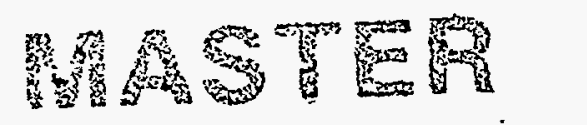




\section{DISCLAIMER}

This report was prepared as an account of work sponsored by an agency of the United States Government. Neither the United States Government nor any agency thereof, nor any of their employees, makes any warranty, express or implied, or assumes any legal liability or responsibility for the accuracy, completeness, or usefulness of any information, apparatus, product, or process disclosed, or represents that its use would not infringe privately owned rights. Reference herein to any specific commercial product, process, or service by trade names, trademark, manufacturer, or otherwise, does not necessarily constitute or imply its endorsement, recommendation, or favoring by the United States Government or any agency thereof. The views and opinions of authors expressed herein do not necessarily state or reflect those of the United States Government or any agency thereof.

Printed in the United States of America.

This report has been reproduced from the best available copy.

Available to DOE and DOE contractors from the Office of Scientific and Technical information, P. O. Box 62, Oak Ridge, Tennessee 37831; prices available from (615) 576-8401, FTS 626-8401.

Available to the public from the National Technical Information Service, U. S. Department of Commerce, 5285 Port Royal Rd., Springfield, Virginia 22161. 


\section{DISCLAIMER}

Portions of this document may be illegible in electronic image products. Images are produced from the best available original document. 
KCP-613-5518

Distribution Category UC-706

Approved for public release; distribution is unlimited.

\title{
STEREOLITHOGRAPHY MODELS
}

\author{
R. E. Smith
}

Published March 1995

Final Report

R. E. Smith, Project Leader 


\section{CONTENTS}

Section

Page

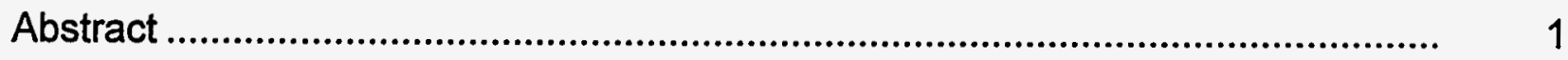

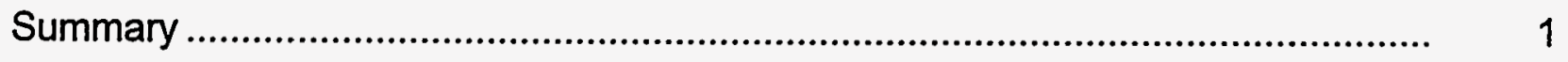

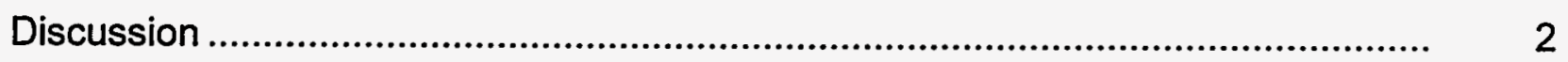

Scope and Purpose .............................................................................. 2

Prior and Related Work ........................................................................... 2

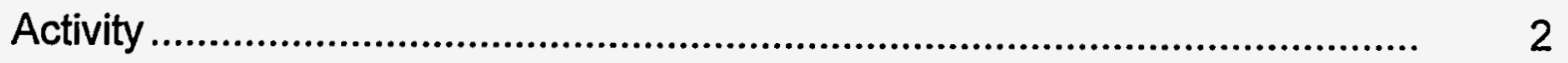

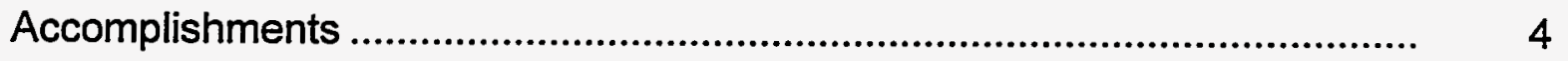

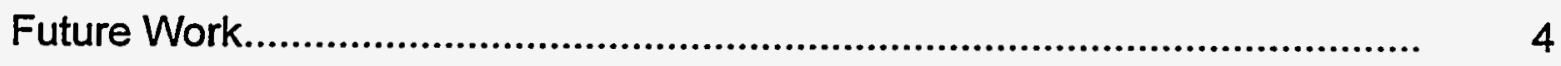

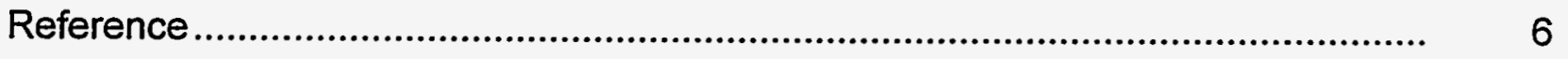

\section{ILLUSTRATIONS}

Figure

Page

1 Stereolithography Model of Benzene...................................................... 3

2 Stereolithography Model of the Variable Domain of the Heavy Chain of the Anti-fluorescein Antibody 4-4-20. 


\section{ABSTRACT}

This report describes the first stereolithographic models made, which proved in a new release of ProEngineer software (Parametric Technologies, or PTC) and 3D Systems (Valencia, California) software for the SLA 250 machine. They are a model of benzene and the $\alpha$-carbon backbone of the variable region of an antibody.

\section{SUMMARY}

New software for the SLA-250 stereolithography machine from 3D Systems (Valencia, CA) and a new version of the CAD software called ProEngineer (PTC) have been proven in by making test parts using Human Genome biomedical models. This exercised the same process attributes that are required for firesets, mechanical products, and compression molding. At the same time, the unique capability to make biomedical models for the Human Genome Project was established at AlliedSignal Inc., Kansas City Division (KCD). This unique capability was supported by a new long-term project entitled Model Making and Prototyping. 


\section{DISCUSSION}

\section{Scope and Purpose}

The project objective was to make test parts to prove in stereolithography software upgrades. This was done by making a model of benzene and the variable domain of the heavy chain of the anti-fluorescein antibody 4-4-20, prepared by the Scripps Research Institute. ${ }^{1}$

\section{Prior and Related Work}

This was the first project of its kind. However, the new version of ProEngineer was acquired as part of the project Accord.

\section{Activity}

A new version of ProEngineer was used to draw a model of benzene, a highly symmetric molecule containing six carbons and six hydrogens arranged in a regular hexagon. The six carbons were drawn as spheres, centered on the vertices of a regular hexagon. The radii of the spheres were increased until the spheres overlapped in what chemists call a space filling model. The six carbons were then represented as smaller spheres, connected by rods, representing chemical bonds, in what chemists call a ball and stick model. The files produced by ProEngineer were converted to a set of triangles that the SLA-250 computer can read. The model, shown in Figure 1, can come apart, with the ball and sticks inside the space-filling model.

Once this was done, programs were written to take a file from the Brookhaven Protein Data Bank and calculate the set of triangles needed to make a model. Upon a recommendation from $D O E$, a model of a portion of an antibody was made from a triangulation file from the Scripps Research Institute, which has a strong interest in antibody structure and molecular graphics. Scripps researchers had already determined the structure of antibodies using X-ray crystallography and had computer images of their structure.

Antibodies are important in fighting diseases. They are made by a type of white blood cell in response to an infection. The antibodies bind to poisons, or pathogens, made by disease organisms. In a healthy immune system, antibodies can help stop and even cure many diseases. The way this is done can be better understood from a detailed knowledge of antibody structure. When a pathogen enters the body of a mammal, white blood cells identify it and make an antibody that will bind to it and set off a cascade of events that eliminates the pathogen. 


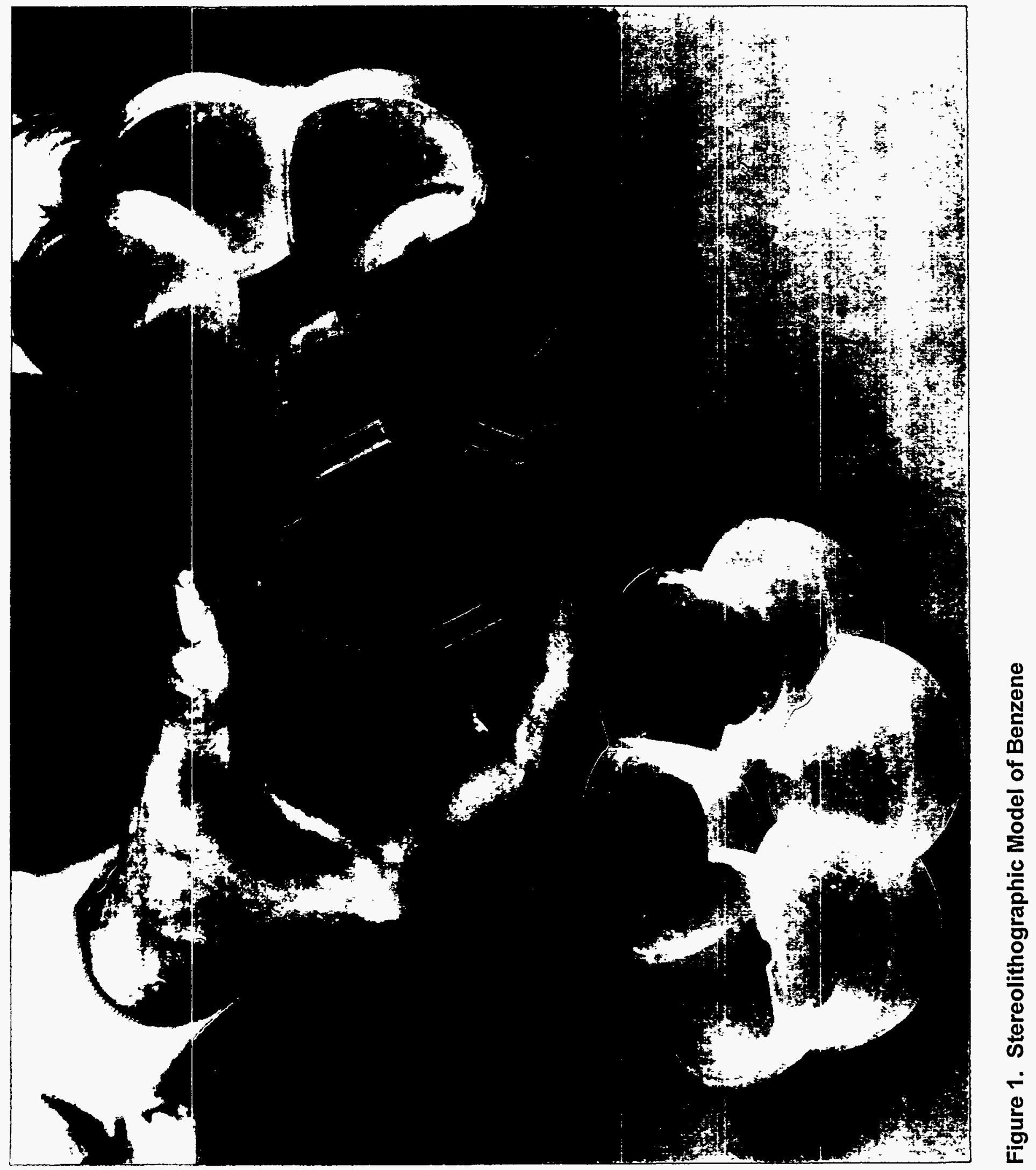


The human body can make about $10^{8}$ different antibodies, enabling one to counter almost any conceivable infection. In addition, antibodies can be modified by genetic engineering to give them enzyme activity, which has potential industrial applications. For these reasons, and because AIDS is a disease of the immune system, workers at Scripps and several other organizations have been solving the structure of antibodies. One of the antibodies they studied was made by injecting a chemical called fluorescein into mice. Their white blood cells recognized it as a pathogen and made an antibody to bind it. From their X-ray crystallographic data, the locations of all atoms except hydrogens in this antifluorescein antibody were obtained. Because an antibody is a type of protein, it is made up of amino acids. To show the backbone of the antibody, only one carbon in each of 118 amino acids was connected with pipes in what is called an $\alpha$-carbon model.

The surface topology of the $\alpha$-carbon model was approximated by a set of triangles. The orientation of the triangles was checked using a program written at $\mathrm{KCD}$. Other programs were written to calculate the normals and barycentric centers to convert the triangulation file into a format suited for stereolithography. A stereolithographic model was made and is shown in Figure 2.

The models of benzene and the antibody proved in the new software. When shown at meetings with biomedical scientists, they created enough interest to enable us to continue this work under a long-term project.

\section{Accomplishments}

The new ProEngineer software for CAD and the 3D Systems software for stereolithography have been proven in. Two models have been made. Enough interest was generated that a long-term project was funded and several more biomedical models were built.

\section{Future Work}

To date, 10 more biomedical models have been made and many more can be made. These models help researchers develop treatments for diseases and help with elementary and middle school science education. One model was even included in the Smithsonian Institution Museum of American History's new exhibit, "Science in American Life." Another model has been delivered to the White House, Office of Media Affairs. It is anticipated that many more models will be built in the future. 


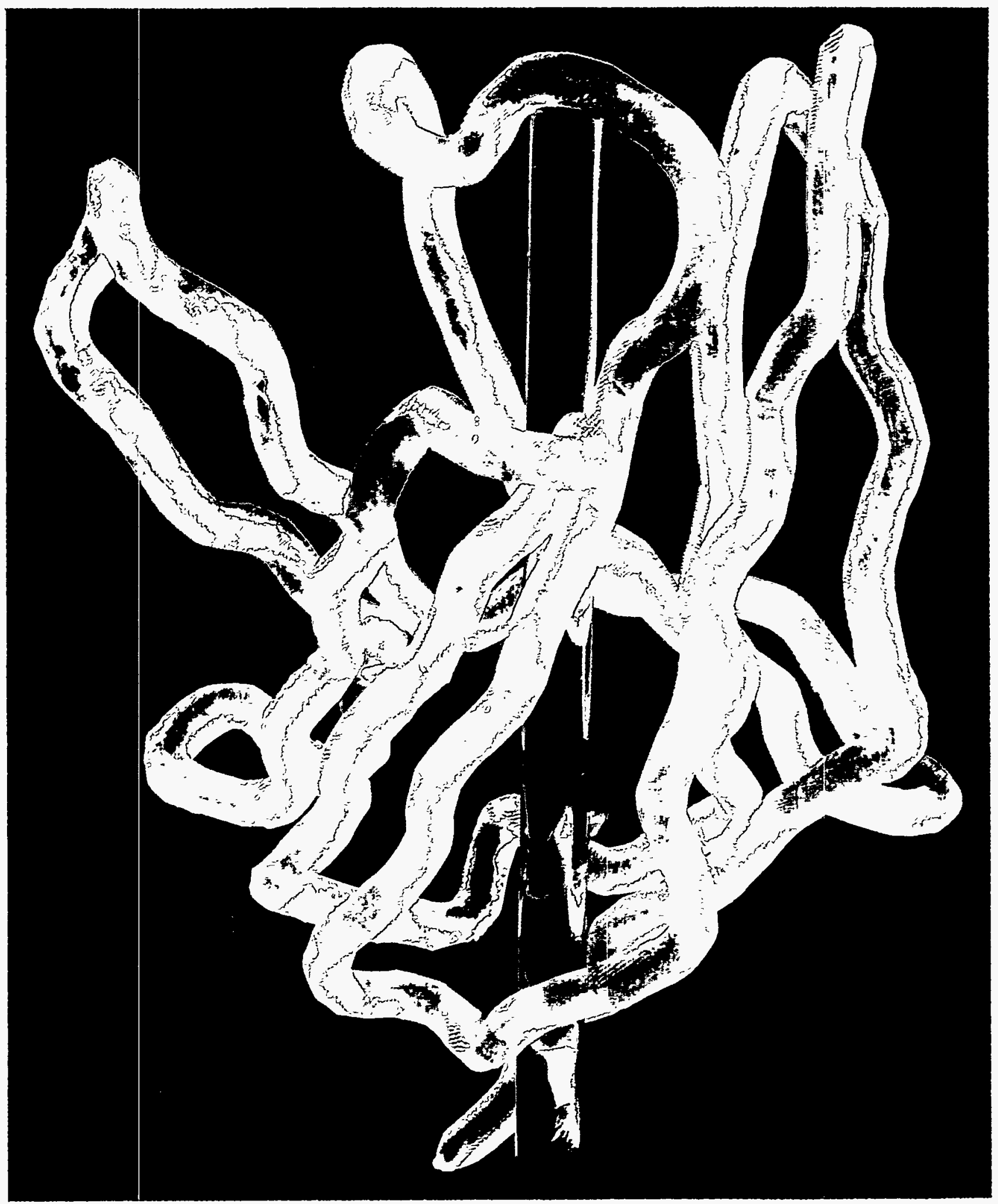

Figure 2. Stereolithography Model ${ }^{1}$ of the Variable Domain of the Heavy
Chain of the Antl-fluorescein Antibody 4-4-20

As described in "Antibody Remodeling: A general solution to the design of a metal-coordination site in an antibody binding pocket" V.A. Roberts, et. al. Proc. Natl. Acad. Sci. USA, Vol. 87, pp. 6654-6658, Sept., 1990.

Data supplied by the Scripps Research Institute, La Jolla, CA 92037.

Model Triangulation by Michael Pique (Scripps) and Jim Emery (AlliedSignal).

Fabricated October 8, 1992, from Exactomer ${ }^{\mathrm{TM}} 2201$ resin by AlliedSignal Inc.,

Kansas City Division, under DOE contract \#DE-AC04-76-DP00613

Copyright $\mathbb{C}$ AlliedSignal Inc., 1992 


\section{Reference}

${ }^{1}$ V.A. Roberts, et al, "Antibody Remodeling: A General Solution to the Design of a Metal-Coordination Site in an Antibody Binding Pocket." Proc. Natl. Acad. Sci. USA, Vol. 87, pp. 6654-6658, Sept. 1990. 